\title{
SPOŁECZEŃSTWO WIEDZY I ORGANIZACJE WIEDZY. O ROLI MENEDŻERÓW W NOWOCZESNYCH PROCESACH SPOŁECZNYCH
}

\begin{abstract}
AвSTRACt. Banaszak Sławomir, Społeczeństwo wiedzy i organizacje wiedzy. O roli menedżerów w nowoczesnych procesach spotecznych [Knowledge Society and Knowledge Organizations. On the Role of Managers in Modern Social Processes]. Studia Edukacyjne nr 46, 2017, Poznań 2017, pp. 49-62. Adam Mickiewicz University Press. ISSN 1233-6688. DOI: 10.14746/se.2017.46.4

Managers are very important part of modern organizations and societies. The paper is an attempt at showing managers as a factor of creating knowledge organizations. The author points at qualifications and competences of managers as the main issue in this process. Problems of "knowledge production" and "knowledge processing" are revealed. The paper ends with the approach to the problems of economic efficiency of knowledge and its positive impact on organizations and societies.
\end{abstract}

Key words: knowledge society, knowledge organization, managers, competencies, knowledge management

\section{Wprowadzenie}

Czy społeczeństwo wiedzy to fakt dokonany? Czy może jeszcze projekt? A co za tym idzie, w jaki sposób traktować współczesne organizacje, zarówno gospodarcze, jak i pozagospodarcze? Czy już są organizacjami wiedzy? Czy zarządza się w nich wiedzą? Odpowiedzi na te pytania nie są oczywiste. Nie tylko zależą od szerokości geograficznej oraz teoretycznej orientacji badaczy, lecz także od ujęcia miejsca i roli menedżerów we wspomnianych procesach. A także w społeczeństwie jako całości ${ }^{1}$.

Niniejszy tekst stanowi próbę odniesienia się do niektórych zasygnalizowanych kwestii, przede wszystkim do społeczeństwa wiedzy i organizacji

\footnotetext{
${ }^{1}$ Por. P.F. Drucker, The rise of the knowledge society, Wilson Quarterly, 1993, 17.
} 
wiedzy, ale właśnie z punktu widzenia zarządców nowoczesnych organizacji. Dlaczego? Ponieważ to ta kategoria osób kreuje i nadzoruje procesy, które prowadzą do uformowania rezultatów w postaci nastawienia na rozwój kwalifikacji i kompetencji, organizacyjnej pamięci i wzrostu znaczenia wiedzy w pracy. Peter Drucker, propagator wspomnianych koncepcji i zwolennik nowoczesnych metod w zarządzaniu, autor pojęcia knowledge workers, nie mylił się, kiedy zasadniczą rolę w nadchodzących przeobrażeniach systemów społecznych i systemów gospodarowania przypisywał menedżerom ${ }^{2}$. Mimo że na taką skalę nie prognozował turbulencji, które znamy zarówno z gospodarki, jak i edukacji ${ }^{3}$.

Współcześnie terminy, jak: społeczeństwo wiedzy, organizacja wiedzy, organizacja ucząca się weszły do kanonu naukowego, przenikają praktykę, są obecne $\mathrm{w}$ wypowiedziach o charakterze publicystycznym. Powtórzmy jednak, że pytanie, czy już wyrażają rzeczywistość, czy pozostają $\mathrm{w}$ fazie „stawania się" jest aktualne. Tym bardziej że zapowiadany wzrost znaczenia wiedzy w gospodarce kosztem kapitału nie dokonał się. Produkcja przemysłowa stanowi wciąż duży udział w PKB rozwiniętych krajów. I z pewnością jest ona bardzo kapitałochłonna. Mimo że oparta na wiedzy, myśli, idei, to jednak jej realizacja wymaga znacznych nakładów finansowych.

Można się oczywiście zgodzić z tezą, iż wiedza znalazła pierwszoplanowe miejsce $w$ strukturze nowoczesnych społeczeństw, gospodarek oraz przedsiębiorstw. W wielu z nich jest też aplikowana w sposób staranny i ostrożny zarazem, ale zawsze z pewnym do niej szacunkiem. Zatem, jakie są relacje wzajemne między wiedzą wytwarzaną przez edukacyjne systemy a wiedzą praktyczną? W jaki sposób współcześni zarządcy „sterują” wykorzystaniem wiedzy przez przedsiębiorstwa oraz organizacje pozagospodarcze? Tym właśnie zagadnieniom poświęcam niniejszy artykuł. Sygnalizuję także konieczność krytycznej analizy zaawansowania procesów gromadzenia i przetwarzania wiedzy do celów gospodarczych oraz pozagospodarczych.

Dwaj amerykańscy autorzy Thomas Davenport i Laurence Prusak zwracają uwagę, iż proces przekształcenia danych $\mathrm{w}$ informacje (a więc mające zdecydowanie bardziej utylitarny charakter) dokonuje się za pośrednictwem następujących „zabiegów”: kontekstualizacji, kategoryzacji, kalkulacji, korekcji, kondensacji ${ }^{4}$. Jakkolwiek obco nie brzmiałyby dla humanisty owe określenia, należy zgodzić się co do zasady. Rzeczywiście bowiem, terminy zaproponowane przez amerykańskich badaczy wyrażają, obecne choćby na gruncie polskiej prakseologii, przekonania co do relacji pomiędzy danymi

\footnotetext{
${ }^{2}$ P.F. Drucker, Społeczeństwo pokapitalistyczne, przekł. G. Kranas, Warszawa 1999.

${ }^{3}$ Por. S. Banaszak, Zarządzanie oświatą w turbulentnym otoczeniu, Studia Edukacyjne, 2013, 27.

4 T.H. Davenport, L. Prusak, Working Knowledge: How Organizations Manage What They Know, Boston 2000, s. 4-6.
} 
a informacjami, między informacjami a aplikacjami i tym podobne. Zatem, pierwszy zabieg polega na osadzeniu konkretnych danych w kontekście, z uwzględnieniem zmian w czasie. Jest to więc również rodzaj analizy historycznej. Wreszcie, kategoryzacja oznacza posłużenie się odpowiednimi jednostkami analizy, które następnie zapewniają porównywalność. Z kolei, kalkulacja i sama kalkulatywność danych oznacza możliwość ich matematycznego przetwarzania. Na etapie korekty dokonuje się, rzecz jasna, usunięcia danych błędnych, a w toku kondensacji następuje wyrażenie informacji $\mathrm{w}$ formie adaptowalnej przez poszczególne jednostki, które mogą następnie wykorzystywać zgodnie z własnymi potrzebami.

W ten sposób uzyskane informacje stają się wiedzą dopiero wówczas, kiedy zachowana jest ich porównywalność, określona mierzalność wywołanych przez nie konsekwencji praktycznych, znana jest ich relacyjność oraz dokonywana przez innych ocena przydatności ${ }^{5}$. Widać wyraźnie, że tezy głoszone przez dwójkę amerykańskich autorów nie noszą znamion absolutnej nowości. Cechy wiedzy zaproponowane przez nich wykazują bowiem bardzo bliskie podobieństwo do tych, jakie opisują naukę. Może poza oceną dokonywaną przez bliżej nieokreślone gremium użytkowników wiedzy. Tym samym, warto podkreślić fakt, iż tak rozumiana wiedza implicite zakłada związek z praktyką, z doświadczeniem. W tym sensie mianowicie, że każda teoria z praktyki wyrasta i - jednocześnie - określa dalsze badania nad praktyką.

\section{Kompetencje w nowoczesnych organizacjach}

Nie ulega wątpliwości, że kompetencje w pracy menedżera są zagadnieniem niezwykłej wagi. Po pierwsze dlatego, że menedżerowie jako zwierzchnicy stanowią specyficzną, w stosunku do pracowników wykonawczych, kategorię. Po drugie zaś, samo pojęcie kompetencji jest obecnie często przywoływane - tak w naukowych publikacjach, jak i w gospodarczej oraz organizacyjnej praktyce, stając się coraz „modniejszym” obiektem rozważań. Ponadto, współcześni zarządcy instytucji gospodarczych oraz pozagospodarczych decydują o strukturze, funkcjonowaniu, zmianie i wreszcie o przystosowywaniu się organizacji do otoczenia

Poszukując wstępnej odpowiedzi na pytanie, czym są kompetencje, nieuchronnie konfrontujemy tę kategorię z „kwalifikacjami”. Proponuję nawet, by nazywać kompetencje kwalifikacjami urzeczywistnionymi w działaniu, co eksponuje ich praktycystyczny odcień. Jednakże, takie ujęcie zakłada cały szereg dodatkowych kryteriów charakteryzujących kompetencje. Jest to przede wszystkim zdolność do przetwarzania wiedzy, traktowania jej jak tworzywa,

\footnotetext{
5 Tamże, s. 4-6.
} 
z którego dopiero dzięki specyficznym umiejętnościom oraz odrębnej wiedzy można uczynić narzędzie skutecznego oddziaływania na rzeczywistość. Ta rzeczywistość nie jest natomiast $\mathrm{w}$ przypadku menedżerów bezosobowa. Tworzą ją ludzie, członkowie organizacji, nieraz równie jej oddani, jak ich zarządcy. Wszystko to sprawia, że w istocie rozróżnienie między kwalifikacjami, mającymi w dużej mierze charakter formalny, a kompetencjami, silnie zorientowanymi na działania, jest celowe. Ponadto, pedagogiczny punkt widzenia musi zakładać jakiś typ wzajemnych relacji pomiędzy wychowaniem, środowiskiem wychowawczym oddziałującym na jednostkę a kompetencjami.

Niemniej, niektórzy badacze traktują pojęcie kwalifikacji i kompetencji jako synonimy. Czyni tak na przykład Stephen P. Robbins ${ }^{6}$, autor znakomitego podręcznika na temat organizacyjnych zachowań, czy Zdzisława Janowska ${ }^{7}$, autorka rodzimego podręcznika do zarządzania zasobami ludzkimi. Jednakże, zdecydowana większość autorów dokonuje rozróżnienia między tymi terminami. Michael Armstrong na przykład, odwołując się do dwóch angielskich słów competency oraz competence, zwraca uwagę, iż termin „kompetencja” ma dwa znaczenia. Jedno z nich dotyczy osób i odnosi się "do wymiarów zachowania leżącego u podstaw kompetentnego działania", z kolei drugie jest związane z pracą „i odnosi się do dziedzin pracy, w których dana osoba jest kompetentna" ${ }^{8}$. Za Spencerem i McClellandem wyróżnia Armstrong składniki kompetencji ${ }^{9}$. Są to: motywy - określane jako wzorzec potrzeb, cechy - oznaczające ogólne predyspozycje wyznaczające sposoby zachowania i reagowania, takie jak: pewność siebie czy samokontrola, samoocena - obejmująca postawy i wartości, wiedza - zarówno techniczna, jak i interpersonalna, wreszcie umiejętności poznawcze i behawioralne - możliwe do zaobserwowania, jak i ukryte, nie poddające się obserwacji ${ }^{10}$.

Według Richarda Boyatzisa, kompetencje należy rozpatrywać w trzech układach, które pozwalają odróżnić jednostki wybitne od przeciętnych. Są to: kompetencje poznawcze, inteligencja emocjonalna oraz kompetencje społeczne. Pierwsze dotyczą między innymi myślenia systemowego i odpowiadają za wzorce działań, drugie obejmują dodatkowo samoświadomość i kontrolę nad samym sobą, trzecie natomiast związane są ze świadomością społeczną

${ }^{6}$ S.P. Robbins, Zachowania w organizacji, Warszawa 1998.

7 Z. Janowska, Zarządzanie zasobami ludzkimi, Warszawa 2002. Por. też S. Chełpa, Kwalifikacje kadr kierowniczych przedsiębiorstw przemysłowych. Kierunki i dynamika zmian, Wrocław 2003, s. 11-18.

8 M. Armstrong, Zarządzanie zasobami ludzkimi, Kraków 2000, s. 243.

9 Nieco inaczej postępuje polska badaczka kompetencji dyrektorów i talentu menedżerskiego w oświacie - por. J. Śmietańska, Talent menedżerski w oświacie, Poznań 2016. Por też. J. Cieślińska, Styl przywództwa dyrektora szkoty a rozwiązywanie konfliktów. Zwiad badawczy, Studia Edukacyjne, 2014, 33.

${ }_{10}$ M. Armstrong, Zarzadzanie zasobami ludzkimi, s. 244. 
i zdolnością do pracy zespołowej. Amerykański uczony zwraca także uwagę, iż generalnie $w$ wypadku współczesnych pracowników większe znaczenie od formalnie rozpatrywanych kwalifikacji mają określone dyspozycje do działania ${ }^{11}$. Przed nim podobne zdanie wyrażał znany polski filozof, logik i prakseolog Tadeusz Kotarbiński.

Zatem, już tylko wstępna analiza kompetencji, wraz z ich elementami składowymi, pokazuje, jak istotne są one $\mathrm{w}$ pracy tych, którzy w praktyce decydują o losach innych ludzi, czyli w pracy profesjonalnych zarządców. Rzecz jasna, wymienione składniki kompetencji mogą być wydzielone w pracy wszystkich kategorii pracowników, jednakże w pracy menedżerów nabierają dodatkowego znaczenia. To w pracy menedżera bowiem, prócz wiedzy i doświadczenia, intuicji, istotne znaczenie ma świadomość w zakresie skutków podjęcia określonych działań i ogólnie rozumiana motywacja ${ }^{12}$.

Znaczenie kompetencji wzmacnia dodatkowo fakt, że jeśli przyjąć, iż wypływając z kwalifikacji o charakterze formalnym, kształtują się pod wpływem doświadczeń, tym większe znaczenie należy przypisać zdolności do wnioskowania i - by tak rzec - katalogowania poszczególnych, napotykanych w toku zawodowej aktywności przypadków. To niezwykle ważna zdolność. Menedżer, który nie potrafi trafnie wnioskować i strukturyzować organizacyjnej rzeczywistości musi być uznany za marnego menedżera. Innymi słowy - menedżer, który nie jest zdolny do uczenia się oraz przyswajania określonych norm i wartości nie jest dobrze przystosowany do pełnienia swej roli zawodowej.

Sądzę, że w świetle niniejszych analiz warto wskazać na konieczność odwoływania się $\mathrm{w}$ analizach miejsca i roli menedżerów $\mathrm{w}$ nowoczesnych organizacjach do dorobku pedagogiki jako nauki badającej procesy uczenia się i socjalizacji. Być może nie jest to teza szczególnie oryginalna, niemniej literatura przedmiotu obfituje raczej $\mathrm{w}$ pozycje pisane $\mathrm{z}$ perspektywy nauk o zarządzaniu, czy nawet nauk ekonomicznych. Można by nawet sformułować tezę, że specjaliści z tych dziedzin zmonopolizowali to naukowe poletko. Przy czym, obecnie krystalizuje się już wyraźna tendencja do ujęć transdyscyplinarnych i wieloaspektowych, które pełniej opisują tak organizacyjną, jak i makrospołeczną rzeczywistość.

Jest przy tym rzeczą oczywistą, że praca ludzka, mimo iż jest źródłem utrzymania, to jednak eksponowanie wyłącznie funkcji ekonomicznej byłoby nietrafne. Prócz niej istotne, a nawet równie istotne, jest kształtowanie oso-

11 R.E. Boyatzis, Competencies in the 21st century, Journal of Management Development, 2008, 1, s. 6-11.

12 Por. J. Skrzypczak, Tak zwane kompetencje kluczowe, ich charakter i potrzeba kształtowania w toku edukacji ustawicznej, [w:] Edukacja ustawiczna w zmieniającej się sytuacji edukacyjnej. Wybrane problemy, red. T. Aleksander, J. Skrzypczak, Poznań 1998, s. 20-22. Por. też B. Baraniak, Człowiek $w$ procesie pracy z perspektywy kierowania i zarzadzania, [w:] Socjologiczne, pedagogiczne i psychologiczne problemy organizacji i zarządzania, red. S. Banaszak, K. Doktór, Poznań 2009. 
bowości i tożsamości przez pracę $e^{13}$. Pedagodzy pracy już od dawna zwracają uwagę, że relacje między człowiekiem, wychowaniem a pracą stanowią nie tylko przedmiot dociekań naukowych, lecz przede wszystkim trwały i niezwykle istotny element organizacyjnego życia ${ }^{14}$.

Wracając zatem do relacji wzajemnych między kwalifikacjami i kompetencjami, należy stwierdzić, że choć desygnaty tych pojęć wzajemnie się uzupełniają i warunkują, to dziś, w warunkach tworzącego się społeczeństwa wiedzy oraz rosnącego znaczenia wiedzy w organizacji, ważniejsze są kompetencje. To one bowiem realnie odzwierciedlają zdolność jednostek do aplikowania wiedzy, a nie wyłącznie do jej gromadzenia. Co więcej, ta praktyczna umiejętność aplikowania wiedzy wydaje się obecnie jednym z najważniejszych aspektów funkcjonowania nowoczesnych organizacji, zarówno gospodarczych, jak i pozagospodarczych. Niemniej, pojęcie kwalifikacji pozostaje wciąż użyteczne, ponieważ pozwala ustalić swoisty punkt wyjścia jednostkowej zdolności do pracy, a także umożliwia rozpoznanie relacji między tym co zgromadzone i tym co efektywnie wykorzystywane w działaniu ${ }^{15}$.

Tak czyni Urszula Jeruszka, która proponuje pięcioczynnikową koncepcję rozwoju kwalifikacji zawodowych. Są to:

1) właściwości biopsychiczne obejmujące właściwości dziedziczne, sprzyjające objawianiu się "pierwiastka genetycznego" w składnikach kwalifikacji oraz inne wyznaczniki ogólnej kondycji biologicznej i psychicznej człowieka; 2) środowisko społeczno-wychowawcze: rodzina, instytucja kształcąca (szkoła/placówka oświatowa), przedsiębiorstwo/praca zawodowa; 3) własne dążenia, u podstaw których tkwi osobowy układ uznawanych wartości oraz własne działania poznawcze umysłowe i praktyczne; 4) środowisko techniczne, uwarunkowane historycznie rozwojem cywilizacji technicznej, technik informatycznych, informacyjnych i telekomunikacyjnych, technologii informacyjnych i komunikacyjnych; 5) wymagania gospodarki, zmiany w strukturze gospodarki i w strukturze zatrudnienia, zmiany zapotrzebowania rynku pracy na określone kwalifikacje zawodowe, którym towarzyszą zmiany w jakościowej strukturze kwalifikacyjnej pracujących ${ }^{16}$.

Jakkolwiek autorka model ten zaaplikowała do badania kwalifikacji uczniów kończących szkołę zawodową, to można - jak sądzę - jej podejście

${ }_{13}$ M. Strykowska, Adaptacyjna funkcja tożsamości zawodowej, [w:] Funkcjonalne i dysfunkcjonalne zjawiska organizacyjne, red. M. Strykowska, Poznań 2007, s. 22-35.

${ }^{14}$ Por. w tym przedmiocie T.W. Nowacki, Wychowanie przez prace, wyd. II, Warszawa 1966; tenże, Praca i wychowanie, Warszawa 1980; S. Kaczor, Kwalifikacje społeczno-moralne i ich rosnace znaczenie w życiu, [w:] Kwalifikacje zawodowe na wspótczesnym rynku pracy, red. S.M. Kwiatkowski, Warszawa 2004; Z. Wiatrowski, Podstawy pedagogiki pracy, wyd. IV, Bydgoszcz 2005; B. Baraniak, Człowiek w procesie pracy.

${ }_{15}$ Por. S. Banaszak, Edukacja menedżerska w społeczeństwie wspótczesnym. Studium teoretyczno-empiryczne, Poznań 2011.

${ }_{16}$ U. Jeruszka, Kwalifikacje zawodowe. Poglady teoretyczne a rzeczywistość, Warszawa 2006, s. 155-157. 
zuniwersalizować. Tym samym, w badaniach i analizach nowoczesnych organizacji, zwłaszcza w ich funkcjach edukacyjnych, owa pięcioczynnikowa koncepcja rozwoju kwalifikacji zawodowych ujawnia swoją przydatność. Sądzę, że zwłaszcza punkty: 2, 3 i 5 mieszczą się w ramach socjopedagogicznego ujęcia kwalifikacji.

W przypadku zarządców nowoczesnych organizacji warto również, za Peterem Druckerem, wzbogacić propozycję polskiej badaczki o fakt, iż współczesne organizacje oraz gospodarki wymuszają stosowanie wiedzy w pracy. Drucker sądzi nawet, że jedną z funkcji organizacji jest „przekładanie wielu różnych dziedzin wiedzy na produktywność"17. Dodatkowo, ponieważ wiedza jest zmienna i podlega stałym przeobrażeniom, każda organizacja musi wpisać w strukturę swoich działań zarządzanie zmianą.

Jeruszka podkreśla z kolei, iż kwalifikacje to część osobowości człowieka. Za Korabiowską-Nowacką i Czarneckim wprowadza ona następującą definicję osobowości zawodowej:

to układ cech psychofizycznych, który zapewnia aktywny kontakt człowieka z materialnym i społecznym środowiskiem pracy, przyczyniającym się do jego twórczych przeobrażeń. Taki układ obejmuje umiejętności zawodowe (umysłowe i praktyczne), charakterystyczne przyzwyczajenia mające znaczenie dla wykonywania zawodu, pewne sposoby rozwiązywania problemów praktycznych, a także cechy charakteru, zainteresowania i zamiłowania zawodowe, zdolności i talenty, system wartości, norm i ocen związanych z wykonywanym zawodem. Ważną cechą osobowości zawodowej jest pozytywny stosunek do zawodu, a także umiejętności i ciągłe dążenie do samokształcenia i samodoskonalenia ${ }^{18}$.

Wyraźnie widać, że przywołana definicja umieszcza w strukturze osobowości zawodowej szereg wzajemnie powiązanych elementów, których charakter należałoby określić jako uniwersalny. Oznacza to, że zasadniczego kształtu tej struktury nie naruszają chyba współczesne przemiany pracy oraz - szerzej - przemiany struktur gospodarczych nowoczesnych społeczeństw. Warto również dodać, że to, co autorka nazywa pozytywnym stosunkiem do zawodu można określić klasycznie - mianem powołania. Powołanie nie ma charakteru metafizycznego - $\mathrm{w}$ najprostszym ujęciu jest ono po prostu cieszeniem się z wykonywanego zajęcia. Ma to swoje konsekwencje zarówno dla samej pracy, w szczególności jej efektywności, jak i dla równoważenia społecznej osobowości jednostki. W przypadku wielu kategorii zawodowych przejawia się także $\mathrm{w}$ zdolności do pracy za wynagrodzeniem o charakterze nieekwiwalentnym w stosunku do nakładu kompetencji i sił. Jak się wydaje, niektóre kategorie menedżerów można włączyć do szerszego zbioru pracowników, dla których płaca nie ma charakteru pełnego ekwiwalentu za pracę.

${ }_{17}$ P.F. Drucker, Społeczeństwo pokapitalistyczne, s. 46.

${ }^{18}$ U. Jeruszka, Kwalifikacje zawodowe, s. 147. 
Nie ulega wątpliwości, że „kwalifikacje” i „kompetencje” są dziś niezwykle ważnymi narzędziami analizy rzeczywistości edukacyjnej i organizacyjnej. Obydwa pojęcia, jak i obie rzeczywistości (choć lepiej byłoby mówić o dwóch strukturach nowoczesnych społeczeństw) wchodzą ze sobą we wzajemne relacje, warunkując się i przenikając. Stąd wyraźne zakreślenie ich odrębności wydaje się celowe - tak z metodologicznego, jak i praktycznego punktu widzenia. Takiego niełatwego zadania podjął się znany polski ekonomista Józef Orczyk, który przekonuje nas o związku jednych i drugich z pracą. Mówiąc skrótowo, kwalifikacje wiążą się z przygotowaniem do podjęcia pracy zawodowej, a z kolei kompetencje są ściśle związane z zakładem pracy oraz - dodajmy - z pracodawcą, który za ich rozwój jest współodpowiedzialny ${ }^{19}$.

Rzeczywiście, zakreślenie przez Orczyka wyraźnej linii demarkacyjnej pomiędzy kwalifikacjami a kompetencjami, przy jednoczesnym uznaniu, iż w dużym zakresie kategorie te zachodzą na siebie, jest ciekawe. Myślę tu zwłaszcza o podmiotach „odpowiedzialnych” za kształtowanie jednych i drugich. W pierwszym przypadku będzie to bowiem szkoła czy uczelnia, w drugim natomiast zakład pracy.

\section{Edukacja w organizacjach wiedzy}

Peter Ferdinand Drucker, nazywany zrazu największym teoretykiem, uczonym, wreszcie wprost guru zarządzania naszych czasów, tak oto ujął miejsce i rolę szkoły w społeczeństwach pokapitalistycznych:

Szkoła, jak powiedziano wcześniej, była tradycyjnym miejscem, gdzie uczyliśmy się; praca natomiast była tam, gdzie pracowaliśmy. Ta granica będzie stopniowo zamazywana. Szkoła będzie się stawała miejscem, gdzie naukę kontynuują dorośli, nawet jeśli zatrudnieni są w pełnym wymiarze godzin. Ci ludzie będą wracali do szkoły na trzydniowe seminaria, na kurs obejmujący weekend, na intensywny trzyweekendowy warsztat, lub na zajęcia odbywające się przez dwa wieczory w tygodniu i trwające kilka lat, do momentu uzyskania dyplomu. Ale również praca będzie miejscem, gdzie dorośli nadal będą mogli się uczyćc ${ }^{20}$.

Rzeczywiście, prócz „odpowiedzialnej szkoły” znakiem pokapitalistycznych struktur społecznych i gospodarczych jest (lub dopiero stanie się) „odpowiedzialna organizacja”. Oznacza to, że będzie ona wyposażać pracowników w wiedzę. Pracownicy z kolei będą ją przetwarzać, czyniąc z niej użyteczne narzędzie oddziaływania na rzeczywistość. $W$ tym procesie będą również brały udział takie czynniki, jak: osobowość i tożsamość pracowników, czy systema-

${ }^{19}$ J. Orczyk, Wokót pojęć kwalifikacji i kompetencji, Zarządzanie Zasobami Ludzkimi, 2009, 3-4.

${ }_{20}$ P.F. Drucker, Spoteczeństwo pokapitalistyczne, s. 168. 
tyczne branie na siebie zobowiązań w stosunku do organizacji i jej otoczenia. Zresztą, co warto w tym miejscu podkreślić, ta wzmiankowana koncepcja odpowiedzialności obecna jest w myśli Druckera o dawna. Już w latach czterdziestych ubiegłego stulecia, w słynnym studium poświęconym General Motors, amerykański uczony wskazywał na znaczenie odpowiedzialności oraz przywództwa. Następnie szeroką koncepcję odpowiedzialności wplatał do innych $\operatorname{prac}^{21}$.

Ponadto, akcentował wielofunkcyjność organizacji i przeciwstawiał się redukowaniu jej do funkcji ekonomicznej. Wskazywał wprawdzie na fakt pozostawiania tego modelu nowoczesnej organizacji in statu nascendi, jednakże obecnie, po ponad dekadzie od wypowiedzenia tych słów, możemy chyba uznać, iż zasadnicze ich przesłanie częściowo się urzeczywistniło. Jak stwierdził Drucker:

Jesteśmy świadkami powstania całkowicie innej idei, która ma nie tylko zastąpić dotychczasowe koncepcje, ale i wzbogacić je. Owo nowe podejście zakłada, że celem organizacji jest uzyskanie rezultatów na zewwątrz, to znaczy osiągnięcie sukcesów na rynku. Organizacja jest jednak czymś więcej niż pewnym mechanizmem opisanym przez Fayola. Jest także czymś więcej niż organizmem gospodarczym ściśle określonym przez wyniki uzyskane na rynku. Organizacja ma przede wszystkim charakter społeczny. W związku z tym, jej celem jest pełne wykorzystanie mocnych stron osób z nią związanych i zminimalizowanie ich słabych punktów. Jest to w istocie jedyna rzecz, którą organizacja jest w stanie osiągnąć i jedyny powód jej istnienia i konieczność utrzymania ${ }^{22}$.

To z pewnością kontynuacja koncepcji odpowiedzialnej organizacji. Nawet jeśli uznamy, że w jakimś kraju, w tym być może i w Polsce, kwestia tak rozumianej odpowiedzialności to dopiero projekt, a nie realna rzeczywistość (co nota bene nie jest raczej prawdą choć - rzecz jasna - nie może być odniesione do wszystkich bez wyjątku organizacji), to i tak musimy uznać trafność sądów Druckera. Nie tylko zresztą jego, bo przecież znane jest ujęcie Petera Senge'a, który w słynnej już pracy Piąta dyscyplina zwrócił uwagę na możliwości nowych organizacji, które nazywał „uczącymi się" ${ }^{23}$. Otóż, dzięki wiedzy mają one zdolność nie tylko reagowania na zmiany, lecz także ich wymuszania czy - lepiej - kreowania. To bardzo istotny przełom w pojmowaniu miejsca i roli nowoczesnych organizacji. To także istotny wymóg organizacyjny, który może być sformułowany w stosunku do każdego pracownika,

21 P.F. Drucker, Concept of the Corporation, New York 1972; tenże, Management And The World's Work, Harvard Business Review, September-October, 1988; tenże, Menedżer skuteczny, Warszawa 1992.

${ }_{22}$ P.F. Drucker, Wstęp: W kierunku organizacji nowego typu, [w:] Organizacja przyszłości, red. F. Hesselbein, M. Goldsmith, R. Beckhard, przekł. M. Albigowski, A. Janiszewski, Warszawa 1998, s. 20-21.

${ }^{23}$ P. Senge, Piąta dyscyplina. Teoria i praktyka organizacji uczacych się, Warszawa 1998. 
jednakże szczególnie względem tych, którzy planują, organizują i kontrolują ludzką pracę. Menedżerowie są odpowiedzialni za gromadzenie i wykorzystanie wiedzy w organizacji oraz za szkolenie i doskonalenie pracowników. Co więcej, od nich właśnie zależy, czy pracownicy będą odpowiednio zmotywowani do podnoszenia swoich kwalifikacji, uczenia się i dzielenia własną wiedzą z innymi członkami organizacji ${ }^{24}$.

Zatem, jest ogromnym pedagogicznym wyzwaniem takie kształtowanie tożsamości menedżerów, by mogli podejmować niełatwe zadania, które stawiają przed nimi organizacje i - przede wszystkim - rynki. Wyzwanie to nie stoi jedynie przed tradycyjnymi instytucjami kształcenia - na przykład przed uniwersytetem kształcącym w zakresie ekonomii lub nauk o zarządzaniu, lecz także przed nowoczesnymi instytucjami transmisji wiedzy i przed samą organizacją. Innymi słowy, obecnie, jak nigdy dotąd, wiedza pedagogiczna, choćby rozumiana jako sztuka oddziaływania na osobowość i tożsamość jednostki, staje się kluczowa w wielu sferach życia społecznego. Humanistę musi jednak razić redukowanie całego kosmosu zjawisk i procesów organizacyjnych do "zarządzania": zarządza się ludźmi, finansami, procesami, a nawet czasem i wiedzą ${ }^{25}$. Poprzestanę $w$ tym miejscu na uwadze, że takie postępowanie nie sprzyja organizacyjnemu postępowi.

\section{Petera F. Druckera wizja przyszłych organizacji i ich społecznej funkcji}

Ważną konstatacją Petera Druckera, wprowadzoną wprawdzie w ostatnich partiach "Społeczeństwa pokapitalistycznego", jest stwierdzenie o doniosłej roli szkoły w społeczeństwie wiedzy, szkoły przeobrażonej w stosunku do poprzednich modeli, która to szkoła wyda na świat odmienny typ „osoby wykształconej”26. Amerykański uczony podkreśla, że żaden kraj nie zdołał jeszcze utworzyć odpowiedniego systemu kształcenia dla społeczeństwa wiedzy (warto zwrócić uwagę, że należałoby - być może - mówić o tym w czasie przeszłym, bo przecież praca Druckera ukazała się w oryginale w roku 1993).

Postuluje zatem, by nowa szkoła potrafiła zapewnić powszechną umiejętność pisania i czytania na wyższym poziomie aniżeli miało to miejsce dotychczas. Innymi słowy, musi ona dać coś więcej niż samą umiejętność czytania i pisania. Oznacza to o wiele większy nacisk położony na proces zdobywania

24 S. Banaszak, Edukacja menedżerska.

25 Por. I. Nonaka, H. Takeuchi, Kreowanie wiedzy w organizacji. Jak spótki japońskie dynamizuja procesy innowacyjne, przekł. E. Nalewajko, Warszawa 2000. Por. też G. Probst, S. Raub, K. Romhardt, Zarzadzanie wiedza w organizacji, przekł. K. Wacowska, Warszawa 2004.

26 P.F. Drucker, Społeczeństwo pokapitalistyczne, s. 158-177. 
wiedzy, czyli - jak obrazowo stwierdza Drucker - uczenie się jak się uczyć27. Zadaniem szkoły jest więc kształtowanie w ludziach motywacji do nieustannego uczenia się oraz nawyku uczenia się na wszystkich poziomach kształcenia i w każdym wieku. Wreszcie, szkoła musi być otwarta zarówno dla ludzi wykształconych, jak i dla tych, którzy w latach wcześniejszych nie mieli dostępu do edukacji. Peter Drucker podkreśla też, że „potrzebujemy kształcenia wyposażającego $\mathrm{w}$ wiedzę pojmowaną zarówno jako substancję i jako proces, co Niemcy różnicują jako Wissen i jako Können" ${ }^{28}$. Kończy swój wywód postulatem demonopolizacji procesu kształcenia przez szkołę, czyli przeniesieniem edukacji do wszystkich organizacji zatrudniających ludzi. Organizacje te staną się „insty tucjami uczenia się i nauczania, a szkoły stopniowo nawiążą współpracę z pracodawcami i zatrudniającymi organizacjami"29.

Również polscy autorzy idą w ślad za myślą Druckera. Ewa Solarczyk-Ambrozik stwierdza, że wymogiem uczącego się społeczeństwa staje się współpraca instytucji oświatowych ze społecznymi partnerami, której rezultatem są między innymi: lepsze radzenie sobie z problemami rynku pracy, ściślejszy związek kształcenia z wymogami rynku pracy, stymulowanie rozwoju przedsiębiorczości, kształtowanie mobilności pracowników i osób poszukujących pracy ${ }^{30}$. Dodatkowo, polska autorka podkreśla, że przed oświatą, w szczególności zaś przed oświatą dorosłych, stoją współcześnie nowe zadania, których zakres jest ściśle związany z dynamiką przeobrażeń społeczno-gospodarczych i kulturowych ${ }^{31}$. Dodaje także, że

Podstawową przesłanką leżącą u podstaw oczekiwań wobec oświaty dorosłych jest egzystencjalno-społeczne pojmowanie edukacji, jako konsekwencji upodmiotowienia życia ludzi. To upodmiotowienie, wynikające także $\mathrm{z}$ nabywanych przez jednostkę kompetencji edukacyjnych, jest dążeniem do samodoskonalenia i samorealizacji - realizowania własnych potrzeb i aspiracji, życia zorientowanego na pracę, uczestnictwo społeczne, ale także i wypoczynek ${ }^{32}$.

Biorąc pod uwagę nie tylko polskie uwarunkowania oświatowe, społeczne i ekonomiczne, lecz także wpływy globalizacji oraz innych ogólnoświatowych procesów, zwłaszcza w ich wymiarze kulturowym, należy zgodzić się zarówno co do diagnozy, jak i co do projektu zmian. Warto również dodać, iż

27 Tamże, s. 163.

${ }^{28}$ Tamże, s. 161.

${ }^{29}$ Tamże.

${ }^{30}$ E. Solarczyk-Ambrozik, Ksztatcenie ustawiczne w perspektywie globalnej i lokalnej, Poznań 2004, s. 37.

${ }^{31}$ Por. $w$ tym przedmiocie rozważania na temat miejsca i roli całożyciowej edukacji C. Sandu, B.C. Neculau, Continuing professional development - a prerequisite for the development of an organisation in the context of the knowledge society, Journal of Public Administration, 2014, 6.

${ }^{32}$ E. Solarczyk-Ambrozik, Kształcenie ustawiczne, s. 133. 
w przypadku menedżerów owo upodmiotowienie połączone z Druckerowskim „uczeniem się jak się uczyć” wydaje się kluczem do zrozumienia specyfiki i doniosłości oddziaływania tej kategorii społecznej.

Niemniej, nakreślona przez Druckera wizja przyszłości edukacji w nowoczesnych społeczeństwach nosi znamiona przedwczesnego i nieuprawnionego sugerowania się dynamicznymi przemianami, jakie miały miejsce przede wszystkim w Europie, ale i na świecie, na przełomie lat osiemdziesiątych i dziewięćdziesiątych ubiegłego stulecia. Tym samym, można by ją nazwać optymistyczną, gdyż traktuje niektóre ledwie zarysowane tendencje jako początek gruntownych przemian. Niemniej, sam fakt dostrzeżenia tych nikłych tendencji oraz - z całą pewnością - uchwycenia ich struktury musi być doceniony, tym bardziej że książka dała początek rozważaniom na temat organizacji i społeczeństwa wiedzy. Przejawia się tu chytrość rozumu badacza społeczeństwa jako skomplikowanej struktury współzależnych elementów, w tym wiedzy, władzy, zarządzania i edukacji.

\section{Zakończenie}

Współcześni menedżerowie prócz tradycyjnych zadań związanych z planowaniem, organizowaniem, motywowaniem i kontrolowaniem pracowników są odpowiedzialni za wykorzystanie wiedzy w pracy. Właśnie te kategorie: odpowiedzialności i wiedzy stanowią wyraźny i niepowtarzalny rys nowoczesności. Inną sprawą jest, rzecz jasna, czy wiedzą w organizacji „zarządza się" w ścisłym sensie czy też nie. Niemniej, wykorzystanie wiedzy, po uprzednim jej przetworzeniu i przystosowaniu do konkretnych zastosowań, jest zadaniem niełatwym, lecz koniecznym. Czy menedżerowie potrafią to robić? Najlepsi tak. Pozostali muszą się tego nauczyć. Inaczej nie będą rozwijać organizacji, na czele których stoją. Dotyczy to zarówno przedsiębiorstw, jak i organizacji pozagospodarczych, w tym stowarzyszeń, fundacji, urzędów czy uniwersytetów.

W każdym wypadku to menedżerowie są głównymi aktorami wspomnianych oddziaływań oraz przemian. To od ich kompetencji, od ich nastawienia do swoich współpracowników zależy, czy organizacje staną się rzeczywistymi organizacjami wiedzy, w których wiedzę się wytwarza, przetwarza oraz aplikuje czy też staną się miejscem wykonywania obowiązków pod presją czasu i wyniku.

Punktem wyjścia niniejszego artykułu stało się przekonanie, że współcześni pracownicy chcą się uczyć. Niezależnie od motywacji: autotelicznych czy instrumentalnych, w efekcie „uzyskamy” społeczeństwo oraz - węziej - organizacje wiedzy. Odrębne jest pytanie o perspektywę tych przemian. Wydaje 
się jednak, że duża część tych procesów już się rozpoczęła i „nowoczesnośćc oznacza dla organizacji stawianie edukacji w centrum uwagi, a nie na peryferiach funkcjonowania. Nie oznacza to wprawdzie, że wszystko jest edukacją, ale na pewno wiąże się z traktowaniem edukacji jako niezwykle doniosłej dla różnych struktur. A z całą pewnością dla formowania się organizacji wiedzy oraz społeczeństwa wiedzy.

\section{BIBLIOGRAFIA}

Armstrong M., Zarządzanie zasobami ludzkimi, Oficyna Ekonomiczna, Kraków 2000.

Banaszak S., Edukacja menedżerska w społeczeństwie wspótczesnym. Studium teoretyczno-empiryczne, Wydawnictwo Naukowe UAM, Poznań 2011.

Banaszak S., Zarządzanie oświatą w turbulentnym otoczeniu, Studia Edukacyjne, 2013, 27.

Banaszak S., Edukacja menedżerska: geneza i znaczenie w nowoczesnych społeczeństwach, Studia Edukacyjne, 2015, 35.

Baraniak B., Człowiek w procesie pracy z perspektywy kierowania i zarzadzania, [w:] Socjologiczne, pedagogiczne i psychologiczne problemy organizacji i zarzadzania, red. S. Banaszak, K. Doktór, Wydawnictwo WSKiZ, Poznań 2009.

Boyatzis R.E., Competencies in the 21st century, Journal of Management Development, 2008, 1.

Chełpa S., Kwalifikacje kadr kierowniczych przedsiębiorstw przemysłowych. Kierunki i dynamika zmian, Wydawnictwo Akademii Ekonomicznej, Wrocław 2003.

Cieślińska J., Styl przywództwa dyrektora szkoty a rozwiązywanie konfliktów. Zwiad badawczy, Studia Edukacyjne, 2014, 33.

Davenport T.H., Prusak L., Working Knowledge: How Organizations Manage What They Know, Harvard Business School Press, Boston 2000.

Drucker P.F., Concept of the Corporation, A Mentor Book, New York 1972.

Drucker P.F., Management And The World's Work, Harvard Business Review, September-October, 1988.

Drucker P.F., Menedżer skuteczny, Czytelnik, Warszawa 1992.

Drucker P.F., The rise of the knowledge society, Wilson Quarterly, 1993, 17.

Drucker P.F., Wstęp: W kierunku organizacji nowego typu, [w:] Organizacja przyszłości, red. F. Hesselbein, M. Goldsmith, R. Beckhard, przekł. M. Albigowski, A. Janiszewski, Business Press, Warszawa 1998.

Drucker P.F., Społeczeństwo pokapitalistyczne, przekł. G. Kranas, Wydawnictwo Naukowe PWN, Warszawa 1999.

Janowska Z., Zarządzanie zasobami ludzkimi, Polskie Wydawnictwo Ekonomiczne, Warszawa 2002.

Jeruszka U., Kwalifikacje zawodowe. Poglady teoretyczne a rzeczywistość, Instytut Pracy i Spraw Socjalnych, Warszawa 2006.

Kaczor S., Kwalifikacje społeczno-moralne i ich rosnace znaczenie w życiu, [w:] Kwalifikacje zawodowe na wspótczesnym rynku pracy, red. S.M. Kwiatkowski, Instytut Badań Edukacyjnych, Warszawa 2004.

Nonaka I., Takeuchi H., Kreowanie wiedzy w organizacji. Jak spótki japońskie dynamizuja procesy innowacyjne, przekł. E. Nalewajko, Poltext, Warszawa 2000.

Nowacki T.W., Wychowanie przez prace, wyd. II, Nasza Księgarnia, Warszawa 1966. 
Nowacki T.W., Praca i wychowanie, Instytut Wydawniczy CRZZ, Warszawa 1980.

Orczyk J., Wokót pojęć kwalifikacji i kompetencji, Zarządzanie Zasobami Ludzkimi, 2009, 3-4. Probst G., Raub S., Romhardt K., Zarządzanie wiedza w organizacji, przekł. K. Wacowska, Oficyna Ekonomiczna, Warszawa 2004.

Robbins S.P., Zachowania w organizacji, Polskie Wydawnictwo Ekonomiczne, Warszawa 1998.

Sandu C., Neculau B.C., Continuing professional development - a prerequisite for the development of an organisation in the context of the knowledge society, Journal of Public Administration, Finance \& Law, 2014, 6.

Senge P., Piąta dyscyplina. Teoria i praktyka organizacji uczacych się, Dom Wydawniczy ABC, Warszawa 1998.

Skrzypczak J., Tak zwane kompetencje kluczowe, ich charakter i potrzeba kształtowania w toku edukacji ustawicznej, [w:] Edukacja ustawiczna w zmieniającej się sytuacji edukacyjnej. Wybrane problemy, red. T. Aleksander, J. Skrzypczak, Eruditus, Poznań 1998.

Solarczyk-Ambrozik E., Ksztatcenie ustawiczne w perspektywie globalnej i lokalnej, Wydawnictwo Naukowe UAM, Poznań 2004.

Strykowska M., Adaptacyjna funkcja tożsamości zawodowej, [w:] Funkcjonalne i dysfunkcjonalne zjawiska organizacyjne, red. M. Strykowska, Wydawnictwo Naukowe UAM, Poznań 2007.

Śmietańska J., Talent menedżerski w oświacie, Wydawnictwo Naukowe UAM, Poznań 2016.

Wiatrowski Z., Podstawy pedagogiki pracy, wyd. IV, Wydawnictwo Akademii Bydgoskiej im. Kazimierza Wielkiego, Bydgoszcz 2005. 